\title{
Territorial Distribution of Business Processes as a Source of Increasing Competitiveness in Companies
}

\author{
Elena A. Kandrashina ${ }^{1}$ \\ Irina A. Shvedova ${ }^{1}$ \\ ${ }^{1}$ Samara State University of Economics, St. The Soviet Army, 141, Samara, Russian Federation \\ Correspondence:Irina Shvedova, Samara State University of Economics, 443090, Russia, Samara \\ Sovetskoi Armii Street, 141, Email: shvedova.irina@mail.ru
}

\author{
Doi:10.5901/mjss.2015.v6n6s3p503
}

\begin{abstract}
Globalization of the economy has changed the nature of competition. Territorial distribution of units, engaged in these or other business processes, assumed the character of an independent source of competitive advantage. The article discusses the features of a modern approach to management of geographically distributed companies. To characterize the dynamics of spatial distribution of business processes the authors define the concepts of "presence region", "base region", "home region" and "key region", which define characteristics of regions where the company can carry out its activities. The authors show that geographically distributed business processes are sources of the company's growth and ways to strengthen its competitiveness, not only due to the choice of the optimal placement of its business processes, but also due to their coordination. The article identifies the benefits and disadvantages of spatial distribution and spatial concentration of business processes. Studying the basis of features of regional development in the Russian Federation the authors conclude that for Russian companies the territorial expansion of activities within the boundaries of the country's complexity and scale is comparable to the process of internationalization of foreign companies' activities.
\end{abstract}

Keywords: business processes, spatial distribution, corporate networks, competitive advantages, presence region.

\section{Introduction}

At the present stage of development in the market economy, characterized by an increasing level of competition, to be successful the company should have a necessary condition - a sustainable competitive advantage, i.e., superiority over competitors by offering customers more consumer value (Kotler 1996).

It should be noted that competitive advantages are not absolute but relative, that is shown in their dependability on spatio-temporal conditions of use (Azoev 2000). On the one hand, the value proposition of the company, which has superiority over competitors in the same region, can be recognized by consumers as uncompetitive in another region due to regional peculiarities of demand conditions. On the other hand, if the new trends in the market are not adequately reflected in the product offer of the company, then over time the company's offer could be less attractive for customers and the company's existing superiority over competitors will lose its significance.

According to modern approaches to the theory of competition, we can consider territorial distribution of business processes as a source of competitiveness.

The new millennium was marked by the strong growth of competition, and the nature of competition is increasingly global. A characteristic feature of the world economy was massive formation of corporate networks, i.e. companies with a set of geographically distributed business processes. The practice of using geographically distributed business processes is widespread in Russia. But for foreign companies spatial distribution of business processes is transboundary in nature, for most Russian companies spatial distribution of business processes is interregional, without crossing national borders, and character.

\section{Literature Review}

The importance of the spatial aspect in formation of the strategy was noted in the early 1970s, by Alfred Chandler - one of the founders of strategic approaches to management. He believed that the strategy is determination of the basic longterm goals and objectives of the organization, adopting a course of action and allocation of resources needed to meet 
these objectives (Chandler, 1977).

In the early 1980s, Michael Porter proposed the theory of competitive advantage, which implies the need to control the elements of the value chain, located in different regions. According to Michael Porter, configuration creates a competitive advantage by selecting specific locations for implementation of each element of the value chain (Porter 2000).

Since the mid-1990s there have been many research papers in which regional space is viewed from position of the network economy. Particular attention should be paid to M. Enright's work (Enright 1993), which illustrates the network availability of firms as an important element of individual competitiveness.

In addition, during the study period, scientists have paid attention to emergence of a new phenomenon in the world economy: companies have formed a group, which, since its inception, seeks a competitive advantage by acquiring resources and sales in many countries, these vendors are called innate globalists (Hollensen 2014).

\section{Main Findings}

The current stage in development of the spatial component in management of the company is characterized by changes in understanding of decision frequency on territorial distribution of business processes in selection of the object, subject and purpose of managing geographically distributed business processes. Features of the modern management approach can be summarized as following:

1) decisions on configuration of customer value chain are considered as part of the business development strategy and are subject to periodic review;

2) as the object of territorial distribution there are not only business processes, but also their combination, providing the greatest contribution to customer value created by the company;

3) geographically distributed business processes are a source of growth and strengthen competitiveness not only due to the choice of the optimal placement of business processes, but also due to their coordination;

4) companies of all sizes and from all industries can be a subject of territorial distribution of business processes.

The article considers these features in more detail.

An important feature of the modern approach to management of geographically distributed business processes is the fact that these solutions are dynamic, i.e. territorial distribution of business processes must be changed in accordance with changes in the external and internal environment of the company. As pointed out by Yang Shi - a professor at Cambridge University (UK), who is actively engaged in the study of corporate networks, the choice of location of a business process chain in consumer value cannot be attributed to decisions that are made only once (Shi 2006). Due to constant changes in the ratio of forces acting on the market, such decisions should be reviewed periodically.

To characterize the dynamics of spatial distribution of business processes the authors define the characteristics of the regions in which the company can carry out its activities.

The historical geographical outline of the region, where all divisions of the company were located at the moment of its creation we will call the home region of the company. At the same time, as a rule, the borders of the home region do not go beyond the country borders. The area of the home region depends on the scale of production and type of product to be produced.

The region, where there is a particular business process of the company, will be called - the presence region. At the beginning of their activities all business units tend to be concentrated in one region, i.e., the company develops, following the strategy of geographic concentration of its business processes. The advantages of this strategy are simplicity of the control function, a minimum interference with circulation of information flow between departments and ability to use economies of scale. At the initial stage of development the home region is the sole presence region.

As business develops, having exhausted the available level of resources in the region, the company's management may decide to disperse any elements of its activity.

The base region is where there are structural units of the company, which create preconditions to maximize competitiveness of the company's products for consumers in the region. For example, the presence of warehouse or production department of the company in the region improves the product offering of the company in terms of speed of delivery, and the sales division, service and warranty centers positively affect information support and customers service.

At the initial stage of company's development, the home region is also the base region. If the company is using a strategy of territorial distribution of business processes, some presence regions of the company have to be transformed into the category of base regions.

M. Porter's ideas associated with sources and types of competition have lead to the idea that competitive advantage is not evenly distributed across the regional divisions of the company, but it has a kind of "center of gravity", 
where there is created the largest amount of added value. Thus the "center of gravity" is "a key base" (eng. Home base) of companies, i.e. one of the business units, which contains the bulk of technology, most professionally trained staff and, consequently, the company generates the largest amount of customer value (Porter ME 1998). A key database is the main place of creating a competitive advantage.

The region, where there is a key base is called a key region. The key region may not coincide with the location of the headquarters or residence of top managers or owners of the company. The company's management can control the location of any key database, selecting a region which best combines different groups of sources of competitive advantage. At the initial stage of business development the home region coincides with the key one. As the business develops and there is growth of changes in the external environment, another region can be selected as the key one and it can differ from the home region.

Thus implemented hierarchy of concepts allows visually representing the ratio of presence, home, key and base regions (Fig. 1) where the home region can occupy any position within the base region.

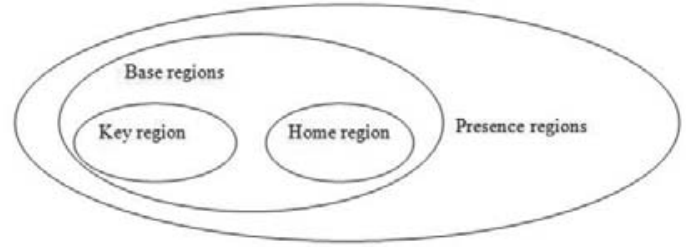

Figure 1. Value concepts of "presence region", "base region", "home region" and "key region".

The study showed a certain type of relationship between the presence region and the size of consumer product formed in the area. Customer value, created by the company, is distributed unevenly among presence regions and reaches its absolute maximum in the key region, and local maxima - in the base region (Fig. 2).

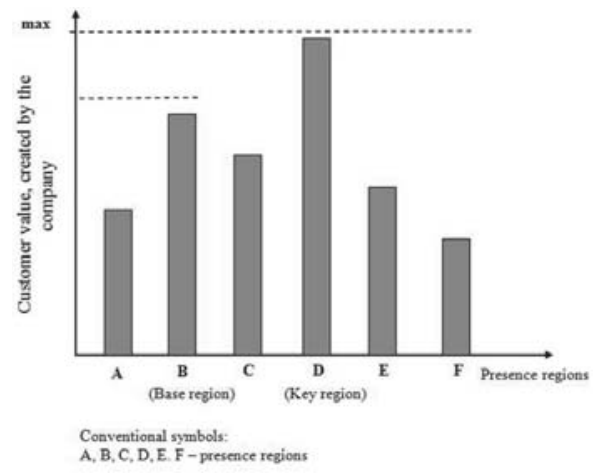

Figure 2. Dependence of customer value, created by the company, on the type of presence region.

To succeed the company needs to integrate competitive advantages due to business processes distributed by regions, and by strengthening the position of the key base. But all business processes included in the "key base" should be concentrated in one region. Territorial distribution of business processes included in the key database, its erosion in several regions could adversely affect the level of competitiveness in the company.

An important feature of the modern approach to management of geographically distributed business processes is recognition of the fact that geographically distributed business processes are sources of the company's growth and strengthen its competitiveness, not only due to the choice of the optimal placement of its business processes, but also due to their coordination.

Differences in regional conditions contribute to globalization of products production, similarity of needs in regional markets to globalization of product sale to consumers. As it is pointed out by L.S. Tarasevich, a famous Russian scientist, 
an author of several books and monographs on international management, economic globalization is manifested through globalization of markets and globalization of goods' production (Tarasevich 2008). Globalization of markets is a process in which companies see a single global market as a target one, which is characterized by a decrease in regional differences in consumer preferences. Globalization of production means distribution of company's operations around the world in order to optimize acquisition of production factors or making production closer to the consumer. Today, the synthesis of configuration value chain and company's way of coordination are considered as an important source of competitive advantage.

Coordination of geographically distributed business processes include exchange of information, sharing of responsibility and coordination of efforts. Coordination as a source of competitive advantage contributes to accumulation of knowledge and experience gained in various places. Due to coordination the company gets an opportunity to respond to changes in the market situation more quickly.

Coordination of geographically distributed business processes is closely linked to configuration of the corporate network. Configuration of the corporate network describes selection of locations for business processes in order to obtain the relative benefits in terms of effectiveness of the particular activity and the number of placements.

Listing various combinations in embodiments of coordination and types of configuration in a value chain, M. Porter offered a matrix of strategies for each of the variants (Fig. 3), which can be used to solve two problems:

- Select development strategy;

- Classify business processes and modeling of the company's activity.

\begin{tabular}{|c|c|c|c|}
\hline \multirow{2}{*}{ 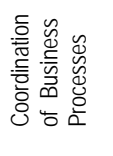 } & 들 & $\begin{array}{l}\text { High degree of territorial dispersion of activities with a high } \\
\text { degree of coordination }\end{array}$ & The global strategy \\
\hline & 흐 & $\begin{array}{l}\text { The national low-centralized strategy for companies with } \\
\text { several regional offices }\end{array}$ & $\begin{array}{l}\text { The strategy, based on the export of goods from the decentralized } \\
\text { territorial marketing. }\end{array}$ \\
\hline
\end{tabular}

Figure 3. M. Porter's matrix of configuration and coordination of business processes (M. E. Porter, 1998).

For classification of business processes and modeling of the company's activity, using Porter's matrix, each business process can get a line in a particular quadrant of the matrix. By changing the placement of company's business processes in the quadrants of M. Porter's matrix, managers can simulate its activities.

Here's an example of company's modeling using M. Porter's matrix for the company "AGC Flat Glass - East", the Russian subsidiary of the world leader in production of flat glass company "AGC Flat Glass". As we can see from Fig. 4, the company "AGC Flat Glass - East" uses various kinds of configuration and coordination for various business processes. An exception is the unit with the lowest coordination of geographically concentrated business processes, which did not hit any of the processes used by the company "AGC Flat Glass - East". This combination of different types of coordination and configuration is possible, but in practice it is extremely rare. As can be seen from Fig. 4 decisions that have a major influence on the company's activity are concentrated in the unit with high coordination and territorial concentration of business processes. The company tries to keep under control the most important business processes. Functions included in the zone of responsibility of the company's headquarters will be located in this part of matrix.

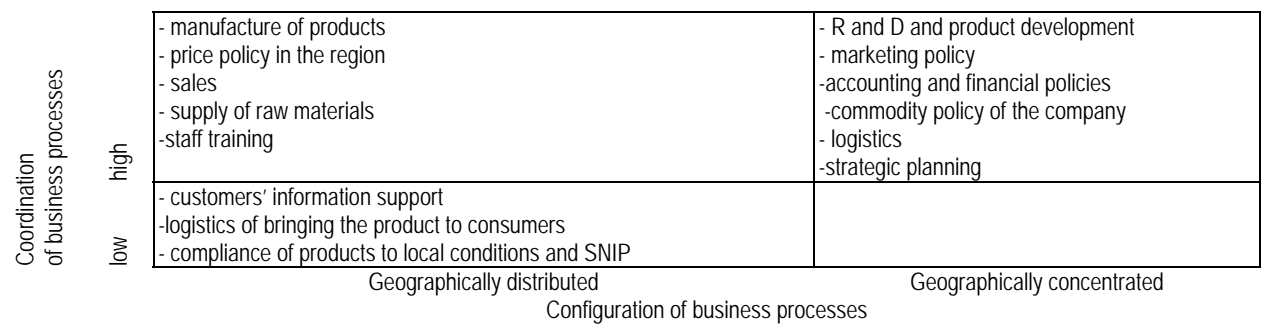

Figure 4. Modeling of business processes in "AGC Flat Glass - East".

It should be noted that M. Porter in his last works stressed the fact that globalization ceased to be a characteristic of the strategy, which is applicable only to large companies. The principal difference of the current stage in evolution of 
theoretical approaches to deployment of business processes is that using this way of gaining a competitive advantage, businesses of all sizes in all industries can benefit. Using configuration and coordination of geographically distributed business processes as a source of competitive advantage is possible for businesses competing at any level, at the level of neighboring towns, regions, neighboring countries or the world economy as a whole, regardless of the industry sector. Thus, the present stage of economic development is characterized by recognition of configuration and coordination of geographically distributed business processes, sources of competitive advantage, both through the use of many placements, and due to advantages of the key base location. At the same time geographically distributed, and geographically concentrated business processes have advantages and disadvantages (Table. 1 and 2).

Table 1. Advantages and disadvantages of using geographically concentrated business processes

\begin{tabular}{|l|l|}
\hline Advantages & Disadvantages \\
\hline 1. The effect of economies of scale & 1. Concentration of risks \\
\hline $\begin{array}{l}\text { 2. The effect of the learning curve (to use employees' skills and } \\
\text { therefore enhance their productivity) }\end{array}$ & 2. Inability to use comparative advantages of regional and cluster development \\
\hline 3. The ease and low cost in coordination of company's activity & 3. Additional costs of delivering products to customers \\
\hline 4. The ease of building relationships with local authorities & $\begin{array}{l}\text { 4. The risk of complex relationships with regional authorities in the sales market, } \\
\text { because local authorities are pursuing a policy of supporting local producers }\end{array}$ \\
\hline $\begin{array}{l}\text { 5. High manageability due to distortion lack in goals transmission, } \\
\text { which are announced by the top management of the company. }\end{array}$ & 5. There are restrictions in gaining knowledge of regional markets \\
\hline
\end{tabular}

Table 2. Advantages and disadvantages of using geographically distributed business processes

\begin{tabular}{|l|l|}
\hline Advantages & Disadvantages \\
\hline $\begin{array}{l}\text { 1. Increase in flexibility of response to meet requirements } \\
\text { of the regional markets }\end{array}$ & 1. The need to build relationships with local authorities \\
\hline 2. High-speed response to changes in the regional market & 2. Increased costs of coordination \\
\hline 3. Allocation of risks & 3.Dependability on dynamics of local tariffs value, exchange rates, taxes, etc. \\
\hline 4.Possibility to take advantage of multiple placements & $\begin{array}{l}\text { 4. Difficulties in transmission of strategies, goals and objectives of the company, its } \\
\text { corporate culture and experience and knowledge between distributed business units. }\end{array}$ \\
\hline
\end{tabular}

For the Russian economy complexity of corporate networks in the country is comparable to complexity of the global network building. This statement is based, on the one hand, on a large extent of the territory of the Russian Federation, on the other - on heterogeneity and individuality of social and economic development of Russian regions.

Taking into account significant differences in socio-economic development of regions in the Russian Federation and their historically developed individuality, companies in the domestic market can be grouped by coverage area of presence regions:

1) The company of the local level, i.e. the company operating in the "home" market, as a rule, does not go beyond the regional center;

2) The company of the regional level, i.e. the company which considers the area, as a target market, geographically limited by economic feasibility of product delivery from the main warehouse in the domestic market, but it goes beyond the regional center.

3) The company of the federal level, working in all economically developed regions of Russia, which has sometimes non-systemic delivery to $\mathrm{CIS}$ countries.

It should be noted that, according to common practice, territorial boundaries of regional markets are identified with administrative borders of the Russian Federation. At the same time, this technique is not always effective, since it does not take into account changes in the level of competitiveness when changing the configuration value chain.

In its scale and complexity the company's transition from a group of local companies into the group of companies of the federal level it is comparable to transition from the group of companies operating in the domestic market into the group of international companies.

Complexity in development of new regional markets within the Russian Federation is not only because of great extent of Russia and underdeveloped transport infrastructure, but in many respects it is based on disparities between regions in the level of economic development and living standards. A characteristic feature of the Russian economy is uneven socio-economic development of regions and increasing growth of competition in markets of the most dynamic regions.

A well-known scientist in the field of regional economy A. Treyvish highlights the main features of the spatial structure in the Russian Federation (Treyvish 2009): 
- Latitude zonation, typical for nature and economy;

- The asymmetry of development at East-West axis;

- The contrasts between centers and periphery;

- The asymmetry of Russian and "other ethnic" regions.

Although the Russian Federation carried out public policies aimed at leveling the socio-economic condition of the region, this kind of gap has always existed. However, since Russia integrates into the world economy, there are tends to expand it. In 1998, the gap in terms of gross regional product (GRP) per capita between different entities of the Russian Federation amounted to 17 times, in 2007 the figure was more than 20 times, the economic crisis led to some reduction in the gap - in 2013 the gap was only 16 times, which, however, is very high (Rosstat, 2014).

According to the Ministry of Regional Development in territorial and economic development of the Russian Federation, more than half of the added value is produced in 13 regions of Russia with high levels of socio-economic development. The maximum amount of GRP is produced in 4 regions - Moscow, the Moscow region, St. Petersburg and the Tyumen region.

The Russian Federation is characterized by high concentration of industrial production: 13 subjects of the Russian Federation are a group of regions with a high level of development, accounting for about $50 \%$ of the total volume of industrial production in Russia. A group of seven regions with a very low level of development produces about $0.4 \%$ of the total industrial output of the Russian Federation.

It should be noted that this trend is not typical to the Russian economy, but to majority of countries whose economies are experiencing an active retraction in the open market. These countries have experienced not only technological, corporate and commercial restructuring of the economy, but also a new territorial concentration of economic activities. This increased disparities in the level of development of regions within the state.

On the basis of mentioned features of regional development in the Russian Federation, we can conclude that for Russian companies the territorial expansion of activity within the boundaries of the country's complexity and scale is comparable to the process of internationalization of foreign companies' activities.

\section{Conclusion}

There is fairly rapid transition from geographically concentrated businesses to geographically distributed corporate networks, just as development of computer technology has demonstrated development of the centralized computer system to the distributed computer network. Today, nobody doubts that the integrated computer network has characteristics and power, which differ from a single computing device. Similarly, the corporate geographically distributed network can have the features and differences from the classical model of enterprises with geographically concentrated business processes. Therefore, management of the geographically distributed corporate network requires special tools, classification, and management practices.

The analysis of theoretical approaches to the problem of developing a strategy of territorial distribution of business processes shows that at the present stage of development of economic knowledge, this problem has been solved only in general terms.

\section{References}

Azoev, G. L. (2000) Competitive advantages of the company [Text] / G. L. Azoev, A. P. Chelenkov ..- M .: of "Typography" News ".

Chandler, Alfred D., Jr. (1977) The Visible Hand: The Managerial Revolution in American Business Cambridge, Mass. and London, England: The Belknap Press of Harvard University Press.

Enright, M.J. (1993) Regional clusters and economic development: a research agenda. - Boston: Harvard Business School.

Hollensen, Svend (2014) Global Marketing, 6th edition, Pearson/

Kotler, Philip, Veronica Wong and Gary Armstrong. (1996) Principles of Marketing - European Edition. Prentice-Hall.

Brewers, S.E., Tarasevich, L. S. (2008) International Management. SPb .: Peter.

Porter, Michael E. (February 2000) Location, Competition and Economic Development: Local Clusters in a Global Economy. Economic Development Quarterly 14, no. 1: 15-34. View Details.

Porter, M.E. (1998) Competitive Strategy: Techniques for Analyzing Industries and Competitors. Free Press. NY.

Shi, Y., Salgado, O. (2006) Plant's role coherence in an international manufacturing network's node / Production and operations management society, Conference.-Shanghai, China.

Treyvish, A. (2009) Spatial Inefficiency and the Downfall of the Soviet Union // Reshaping Economic Geography. World Development Report. 2009. Washigton DC: The World Bank. P. 90-91.

Federal State Statistics Service // http://www.gks.ru/wps/wcm/connect/rosstat_main/rosstat/ru/statistics/account/\# 